\title{
Effects of drying method, storage period and carbon: nitrogen ratio on inorganic nitrogen contents of Vertisols
}

\author{
NINA D. O. and SIGUNGA D. O.* \\ Department of Soil Science, Maseno University, P.O. Box 333 - 40105, Maseno, Kenya. \\ Accepted 3 December, 2012
}

\begin{abstract}
In order to monitor spatial inorganic $\mathbf{N}$ concentrations in soils over time, collected soil samples are composited and thoroughly mixed. The sticky characteristic of Vertisol when wet makes it difficult to thoroughly mix wet samples. There is the need for appropriate drying of Vertisol samples to facilitate thorough mixing and storage to retain mineral $\mathrm{N}$ content reflective of field status. We determined the effects of drying method, storage period and C:N ratio on inorganic $\mathbf{N}$ contents of tropical Vertisols. The treatments comprised of three soils with different $\mathrm{C}: \mathrm{N}$ ratios, five drying methods inclusive of a check (method 1), and five storage periods including a check (period 1). Storage temperature was $-10^{\circ} \mathrm{C}$. In method 1, field-fresh soil samples were kept at $-10^{\circ} \mathrm{C}$ and later used for mineral $\mathrm{N}$ extraction using $0.5 \mathrm{M}$ $\mathrm{K}_{2} \mathrm{SO}_{4}$. Period 1 involved storing soil samples for two days from sampling date before mineral $\mathrm{N}$ extraction. Ammonium- $\mathrm{N}$ and $\mathrm{NO}_{3}-\mathrm{N}$ were determined using colorimetric method. Method 1 x period 1, for each soil, resulted in $\mathrm{NH}_{4}{ }^{+}-\mathrm{N}$ and $\mathrm{NO}_{3}{ }^{-}-\mathrm{N}$ contents significantly different from other treatments indicating that extraction for mineral $\mathbf{N}$ should be done on field moist soil not later than two days after sampling.
\end{abstract}

Key words: Drying method, mineral nitrogen, storage period, soil preparation, Vertisols.

\section{INTRODUCTION}

Nitrogen $(\mathrm{N})$ is the plant nutrient element most limiting to crop performance in the majority of soils in the tropics (Bekunda et al., 2007). In tropical Vertisols, $\mathrm{N}$ is the most universally deficient plant nutrient (Coulombe et al., 1996), and it is the most limiting element to crop production in Vertisols in Kenya (Smaling and Bouma, 1992). Dynamics of $\mathrm{N}$ (that is, transformations and translocations) in soils play important roles in $\mathrm{N}$ cycling, ground water pollution, and $\mathrm{N}$ availability to crops (Stevenson, 1986; Aulakh et al., 1992). Most of soil $\mathrm{N}$ is in organic form $\left(-\mathrm{NH}_{2}\right)$ and is only made available to plants through mineralization to inorganic $\mathrm{NH}_{4}{ }^{+}$and $\mathrm{NO}_{3}{ }^{-}$(Brady and Weil, 2002). Inorganic $\mathrm{N}$ concentrations in a particular soil layer at a point in time reflect the net effects of $\mathrm{N}$ inputs from mineralization, inorganic fertilizers and atmosphere on the one hand, and outputs through plant uptake, leaching, bypass flow, denitrification, volatilization and immobilization on the

\footnotetext{
${ }^{*}$ Corresponding author: Email. dalsigunga@yahoo.com.
}

other hand (Wong and Nortcliff, 1995). Mineralization, immobilization and denitrification are biochemical processes which depend on soil moisture, temperature and carbon (Aulakh et al., 1992) and since these processes vary with time and space, the concentration of soil inorganic $\mathrm{N}$ inevitably varies temporally and spatially. Soil drying and rewetting increases the rate of inorganic $\mathrm{N}$ released from organic form (Birch, 1958; Wong and Nortcliff, 1995). The highest concentration of inorganic $\mathrm{N}$ in the top soil in the tropics is at the transition from the dry season to the wet season. Most of the mineralized $\mathrm{N}$ is lost if its release and plant demand for it are not synchronized. Synchrony requires that the rate of release of a nutrient into a plantavailable form is closely related to the rate at which the nutrient is needed by the plants. Plant uptake of nitrogen depends on positional relationship between plant roots and available $\mathrm{N}$ forms (Wiesler and Horst, 1994). Thus, the $\mathrm{N}$ form available to plants at a given time and at a soil depth is dependent on $\mathrm{N}$ dynamics in the soil in relation to plant roots. Thorough understanding of $\mathrm{N}$ dynamics in the soil is, therefore, prerequisite in formulating strategies to 
Table 1. Physical and chemical properties of the experimental soils

\begin{tabular}{lccc}
\hline \multirow{2}{*}{ Property } & \multicolumn{3}{c}{ Soil sample } \\
\cline { 2 - 4 } & Soil 1 & Soil 2 & Soil 3 \\
\hline \%Sand & 24 & 26 & 27 \\
\%Silt & 13 & 15 & 14 \\
\%Clay & 63 & 59 & 59 \\
Textural class & Clay & Clay & Clay \\
pH water & 5.9 & 5.8 & 5.8 \\
$\% \mathrm{~N}$ & 0.17 & 0.14 & 0.18 \\
$\% \mathrm{C}$ & 2.29 & 2.11 & 2.81 \\
$\mathrm{C}: \mathrm{N} \mathrm{ratio}$ & 13.5 & 15.1 & 15.6 \\
$\mathrm{~K} \mathrm{cmol}(+) \mathrm{kg}^{-1}$ & 0.4 & 0.3 & 0.6 \\
$\mathrm{Mg} \mathrm{cmol}(+) \mathrm{kg}^{-1}$ & 11.3 & 12.3 & 10.8 \\
$\mathrm{Ca} \mathrm{cmol}(+) \mathrm{kg}^{-1}$ & 22.9 & 24.4 & 22.2 \\
$\mathrm{CEC}$ & 38 & 45 & 48 \\
\hline
\end{tabular}

synchronize supply and crop requirement of $\mathrm{N}$ and protect the environment from unutilized $\mathrm{N}$.

In order to monitor the net effects of $\mathrm{N}$ dynamics (that is, inorganic $\mathrm{N}$ concentrations) in soils over time, composite soil sample is collected at time intervals, covering the entire period during which the $\mathrm{N}$ changes are to be determined. Inorganic $\mathrm{N}$ is invariably determined in field-fresh soil samples (Recous et al., 1988; Tripathi and Ladha, 1997) to reflect the position in the soil at the time of sampling (Anonymous, 1995). Soil sampling and sample preparation constitute the most important steps in any soil-testing program. Laboratory analysis does not compensate for poorly collected, poorly prepared or unrepresentative soil sample (Anderson and Ingram, 1993). The collection of a representative soil sample is critical because only small amount ( 10 to $25 \mathrm{~g}$ ) of moist soil is used in analysis. Soil sample, therefore, should be collected from many spots in an experimental plot, composited, thoroughly mixed, and then $200 \mathrm{~g}$ sub-sampled by quartering method (Anonymous, 1995).

The sticky characteristic of Vertisol when wet makes it difficult to thoroughly mix wet composite samples to obtain a representative sample of an area, hence determination of inorganic $\mathrm{N}$ content of Vertisols over a period of time would require some adequate drying of samples to facilitate thorough mixing and storage, but both the drying temperature and the length of storage period have effects on soil extractable nutrients (Houba and Novozamsky, 1998; Magesan et al., 2002; Gray and Mclaren, 2003). Carbon:nitrogen ratio also influences mineralization and immobilization processes (Brady and Weil, 2002). Total soil carbon vary with ecosystem (Bernoux et al., 2002) and soil type (Sakin et al., 2011). The C:N ratio is also influenced by both ecosystem and soil type (Sakin, 2012). We determined the effects of drying method, storage period and $\mathrm{C}: \mathrm{N}$ ratio on inorganic $\mathrm{N}$ contents of tropical Vertisols.

\section{MATERIALS AND METHODS}

\section{Experimental soils}

To characterize the experimental soils, samples were collected from three sites within Muhoroni Division, Kenya, located at $00^{\circ} 10.06^{\prime} \mathrm{S}$, $035^{\circ} 13.50^{\prime} \mathrm{E}$, and at an elevation of $1339.7 \mathrm{~m}$ above sea level. We selected on the basis of different $\mathrm{C}: \mathrm{N}$ ratios. Soil samples were air dried and ground to pass through $2.0 \mathrm{~mm}$ sieve and analyzed for texture, $\mathrm{pH}$, total $\mathrm{N}$, organic carbon, exchangeable bases and cation exchange capacity (CEC). Soil texture was determined by the hydrometer method (Bouyoucos, 1962). Soil pH, total N, organic C, exchangeable $\mathrm{K}, \mathrm{Ca}, \mathrm{Mg}$, and $\mathrm{CEC}$ were determined following methods described by Okalebo et al. (2002). The properties of the experimental soils are summarized in Table 1. Sigunga (1997) classified the soils of the experimental site as pellic-eutric Vertisols according to Anonymous (1997).

\section{Experimental treatments and design}

The treatments comprised of three soils with different C:N ratios, five storage periods, and five drying methods (Table 2). Soil samples awaiting inorganic $\mathrm{N}$ extraction were stored at- $10^{\circ} \mathrm{C}$ in order to minimize biochemical changes during storage (Bremner, 1996). The five levels of drying methods were as follows: in drying method 1 , control (method 1) field-fresh soil samples were kept at $-10^{\circ} \mathrm{C}$ and later used for inorganic $\mathrm{N}$ extraction 2, 5, 10, 20, and 40 days after soil sampling date. Drying method 2 (method 2) involved air drying fieldfresh soil samples at room temperature (ca. $20^{\circ} \mathrm{C}$ ) for two days, then stored at $-10^{\circ} \mathrm{C}$ and later used for inorganic $\mathrm{N}$ extraction on $0,3,8,18$ and 38 days after drying. The first sub-sample in this group was used for inorganic $\mathrm{N}$ extraction immediately after air drying (that is, 0 days after drying). In drying method 3 (method 3 ), field-fresh soil samples stored at $-10^{\circ} \mathrm{C}$ were sub-sampled $0,3,8,18$ and 38 days after sampling date. The sub-samples were air dried at room temperature for two days, and then used for inorganic $\mathrm{N}$ extraction immediately. In drying method 4 (method 4), field-fresh soil samples were oven dried at $60^{\circ} \mathrm{C}$ for two days. The dried samples were cooled in a dessicator, then packed in polyethylene bags and stored at $-10^{\circ} \mathrm{C}$ until inorganic $\mathrm{N}$ extraction on $0,3,8,18$, and 38 days after drying. Drying method 5 (method 5) involved oven drying field-fresh soil samples at $100^{\circ} \mathrm{C}$ for two days. The dried samples were cooled in a dessicator, then packed in polyethylene bags and stored at $-10^{\circ} \mathrm{C}$ until inorganic $\mathrm{N}$ extraction on $0,3,8,18$, and 38 days after drying. The 75 treatments were combined in a factorial arrangement in a completely randomized design (CRD) replicated three times.

\section{Data collection and statistical analysis}

It is not feasible to obtain a composite representative fresh sample of wet Vertisol due to its stickiness that makes thorough mixing before sub-sampling impossible. To go round this problem and also to minimize the impact of spatial heterogeneity in soil properties both in horizontal and vertical directions, a small cylindrical block of soil was excavated using a PVC cylinder 20,10 , and $1.5 \mathrm{~cm}$ in diameter, height and thickness, respectively. Excavated soil samples were immediately placed in polyethylene bags in cool box to avoid loss of water and to minimize biochemical changes during transportation to the laboratory.

In the extraction of inorganic $\mathrm{N}$, about $10 \mathrm{~g}$ of soil sample was mixed with $100 \mathrm{ml}$ of $0.5 \mathrm{M} \mathrm{K}_{2} \mathrm{SO}_{4}$ in a plastic bottle and shaken for $1 \mathrm{~h}$ at 150 reciprocations per minute. The soil extract was filtered using Whatman No. 42 filter paper. The filtrate was stored at $-10^{\circ} \mathrm{C}$ and later analyzed for $\mathrm{NH}_{4}{ }^{+}-\mathrm{N}$ and $\mathrm{NO}_{3}-\mathrm{N}$. Both $\mathrm{NH}_{4}{ }^{+}-\mathrm{N}$ and $\mathrm{NO}_{3}-\mathrm{N}$ were determined as described by Okalebo et al. (2002). Inorganic $\mathrm{N}$ content of the experimental soils was corrected to oven dry weight basis. 
Table 2. Details of treatment factors and levels.

\begin{tabular}{|c|c|c|}
\hline Factor & $\begin{array}{l}\text { Level } \\
\text { designation }\end{array}$ & Level description/characteristic \\
\hline \multirow{3}{*}{ Soil } & Soil 1 & $\mathrm{C}: \mathrm{N}=13.5 ; \% \mathrm{~N}=0.17$ \\
\hline & Soil 2 & $C: N=15.1 ; \% N=0.14$ \\
\hline & Soil 3 & $\mathrm{C}: \mathrm{N}=15.6 ; \% \mathrm{~N}=0.18$ \\
\hline \multirow{5}{*}{$\begin{array}{l}\text { Drying } \\
\text { method }\end{array}$} & Method 1 & Control. Field-fresh soil samples stored at $-10^{\circ} \mathrm{C}$ and later used for inorganic $\mathrm{N}$ extraction. \\
\hline & Method 2 & $\begin{array}{l}\text { Field-fresh soil samples were air dried at room temperature for } 2 \text { days then stored at }-10^{\circ} \mathrm{C} \text { and later } \\
\text { used for inorganic } \mathrm{N} \text { extraction. }\end{array}$ \\
\hline & Method 3 & $\begin{array}{l}\text { Field-fresh soil samples stored at }-10^{\circ} \mathrm{C} \text { were sub-sampled } 0,3,8,18 \text { and } 38 \text { days after collection. The } \\
\text { sub-samples were air dried at room temperature for two days and then used for inorganic } \mathrm{N} \text { extraction } \\
\text { immediately. }\end{array}$ \\
\hline & Method 4 & $\begin{array}{l}\text { Field-fresh soil samples were oven dried at } 60^{\circ} \mathrm{C} \text { for two days. The dried samples were cooled in a } \\
\text { dessicator and stored at }-10^{\circ} \mathrm{C} \text { until inorganic } \mathrm{N} \text { extraction. }\end{array}$ \\
\hline & Method 5 & $\begin{array}{l}\text { Field-fresh soil samples were oven dried at } 100^{\circ} \mathrm{C} \text { for two days. The dried samples were cooled in a } \\
\text { dessicator and stored at }-10^{\circ} \mathrm{C} \text { until inorganic } \mathrm{N} \text { extraction }\end{array}$ \\
\hline \multirow{5}{*}{$\begin{array}{l}\text { Storage } \\
\text { period }\end{array}$} & Period 1 & The soil samples were stored for 2 days from sampling date and then used for Mineral $\mathrm{N}$ extraction \\
\hline & Period 2 & The soil samples were stored for 5 days from sampling date and then used for Mineral $\mathrm{N}$ extraction \\
\hline & Period 3 & The soil samples were stored for 10 days from sampling date and then used for Mineral $\mathrm{N}$ extraction \\
\hline & Period 4 & The soil samples were stored for 20 days from sampling date and then used for Mineral $\mathrm{N}$ extraction \\
\hline & Period 5 & The soil samples were stored for 40 days from sampling date and then used for Mineral $\mathrm{N}$ extraction \\
\hline
\end{tabular}

Table 3. Analysis of variance table of the effects of soils, drying methods and storage periods on mineral nitrogen content ( $\mathrm{mg} \mathrm{N} \mathrm{kg}^{-1}$ oven-dry soil) of the experimental soils.

\begin{tabular}{|c|c|c|c|}
\hline \multirow{2}{*}{ Source of variation } & \multirow{2}{*}{$\begin{array}{l}\text { Degrees of } \\
\text { freedom }\end{array}$} & \multicolumn{2}{|c|}{$F$ value } \\
\hline & & $\mathrm{NH}_{4}{ }^{+}$ & $\mathrm{NO}_{3}^{-}$ \\
\hline${ }^{1}$ Soils & 2 & $11.85^{\star}$ & $224.76^{\star}$ \\
\hline${ }^{2}$ Drying methods & 4 & $285.05^{*}$ & $65.39^{*}$ \\
\hline Soils $\mathrm{x}$ drying methods & 8 & $4.88^{\star}$ & $15.56^{*}$ \\
\hline${ }^{3}$ Storage periods & 4 & $5.71^{*}$ & $14.21^{*}$ \\
\hline Soils $\mathrm{x}$ storage periods & 8 & $5.12^{*}$ & $10.69^{*}$ \\
\hline Drying methods $\mathrm{x}$ storage periods & 16 & $5.55^{\star}$ & $3.21^{*}$ \\
\hline Soils $\mathrm{x}$ drying methods $\mathrm{x}$ storage periods & 32 & $2.47^{*}$ & $3.14^{*}$ \\
\hline Error & 150 & - & - \\
\hline
\end{tabular}

*Indicates significant difference at 0.05 level. ${ }^{1}$ Soils, ${ }^{2}$ drying methods and ${ }^{3}$ storage periods are as explained in Table 2.

Inorganic $\mathrm{N}$ obtained from the extracts was statistically analyzed using analysis of variance (ANOVA), and separation of means due to treatments was done using least significant difference (LSD) with the help of GENSTAT computer software package (Anonymous, 2010).

\section{RESULTS AND DISCUSSION}

\section{Influence of drying methods on mineral $\mathbf{N}$ content of Vertisols}

Drying methods significantly $(\mathrm{p}=0.05)$ influenced the mean $\mathrm{NH}_{4}{ }^{+}-\mathrm{N}$ and $\mathrm{NO}_{3}{ }^{-} \mathrm{N}$ contents of the soils (Table 3). Drying method 1 (Method 1), the control, resulted in significantly $(p=0.05)$ the lowest while Method 5 produced the highest mean $\mathrm{NH}_{4}{ }^{+} \mathrm{N}$ content of the soils, respectively (Table 4). The order was method $5>$ method $4>$ method $3=$ method $2>$ method 1 . Nitrate- $\mathrm{N}$ content of the soils was also significantly influenced by the drying methods with method 1 resulting in the lowest while methods 2 and 3 resulted in the highest $\mathrm{NO}_{3}^{-} \mathrm{-N}$ contents (Table 4). The order was method $3=\operatorname{method} 2>\operatorname{method} 5=\operatorname{method} 4>\operatorname{method} 1$.

The significantly $(\mathrm{p}=0.05)$ lower $\mathrm{NH}_{4}{ }^{+} \mathrm{N}$ contents due to method 1 (control) compared to the other drying methods underscores the effect of drying on $\mathrm{NH}_{4}{ }^{+}-\mathrm{N}$ changes in soils. Nelson and Bremner (1972) found that both air drying in the laboratory for $72 \mathrm{~h}$ and oven drying at $55^{\circ} \mathrm{C}$ for $16 \mathrm{~h}$ produced increase in exchangeable $\mathrm{NH}_{4}^{+}-\mathrm{N}$. Ammonia absorption from the air could also contribute to the 
Table 4. Mean effects of main treatments on mineral nitrogen content (mg N kg${ }^{-1}$ oven-dry soil) of the experimental soils.

\begin{tabular}{lcc}
\hline Main treatment & $\mathbf{N H}_{4}{ }^{+}-\mathbf{N}$ & $\mathbf{N O}_{3}{ }^{-}-\mathbf{N}$ \\
\hline *Soils $(\mathbf{n}=\mathbf{7 5})$ & & \\
Soil 1 & 25.8 & 0.8 \\
Soil 2 & 27.5 & 1.1 \\
Soil 3 & 28.0 & 1.3 \\
LSD $0.05^{-0.9}$ & 0.96 & 0.25 \\
*Drying methods $(\mathbf{n}=\mathbf{4 5 )}$ & & \\
Method 1 & & \\
Method 2 & 18.2 & 0.5 \\
Method 3 & 23.3 & 2.6 \\
Method 4 & 24.2 & 2.5 \\
Method 5 & 33.8 & 1.0 \\
LSD 0.05 & 35.9 & 1.1 \\
& 1.24 & 0.33 \\
*Storage periods $(\mathbf{n}=\mathbf{4 5 )}$ & & \\
Period 1 & & \\
Period 2 & 28.4 & 1.1 \\
Period 3 & 26.3 & 1.2 \\
Period 4 & 27.0 & 1.5 \\
Period 5 & 26.9 & 1.9 \\
LSD 0.05 & 27.2 & 2.2 \\
\hline
\end{tabular}

*Soils, drying methods, and storage periods are as explained in Table

2.

moderate increase in $\mathrm{NH}_{4}{ }^{+}-\mathrm{N}$ content when soils were airdried (methods 2 and 3). Selmer-Olsen et al. (1971) reported that drying soils in open boxes produced more ammonium than drying in trays at $20^{\circ} \mathrm{C}$. The pronounced increase $\mathrm{NH}_{4}{ }^{+}-\mathrm{N}$ content of soils due to oven drying methods (methods 4 and 5) was ascribed to organic and other inorganic sources such as ammonium phosphate complexes that were decomposed during heating and released ammonia which was later retained by cation exchange sites of the soil colloids. Frye and Hutcheson (1981) reported that oven drying increases $\mathrm{NH}_{4}{ }^{+}-\mathrm{N}$ released from soils and that oven drying at $110^{\circ} \mathrm{C}$ released greater amount of $\mathrm{NH}_{4}^{+}-\mathrm{N}$.

The significantly $(\mathrm{p}=0.05)$ lower $\mathrm{NO}_{3}{ }^{-} \mathrm{N}$ contents due to methods 5 and 4 compared to methods 3 and 2 (Table 4) was attributed to high oven drying temperatures (70 and $100^{\circ} \mathrm{C}$, respectively) that could have reduced the activity of nitrifying organisms. The high oven drying temperatures reduced the soil moisture levels and, inevitably, reduced microbial activity. Linn and Doran (1984) reported low microorganism activity at soil moisture contents below $10 \%$ water filled pore space. The high $\mathrm{NO}_{3}{ }^{-} \mathrm{N}$ levels in methods 2 and 3 could be attributed to enhanced mineralization process during air drying of soil samples at room temperature $\left(20^{\circ} \mathrm{C}\right)$. Selmer-Olsen et al. (1971) reported that $\mathrm{NO}_{3}-\mathrm{N}$ increased with time at $20^{\circ} \mathrm{C}$. The significantly $(p=0.05)$ higher $\mathrm{NO}_{3}{ }^{-} \mathrm{N}$ contents of the experimental soils due to methods 3 and 2 than method 1 (control), although all the three treatments involved air drying and storage at $10^{\circ} \mathrm{C}$, indicates that mineralization continued at the low storage temperature. Magesan et al. (2002) also observed that nitrification proceeded during low temperature storage. Much lower storage temperature would, possibly, be necessary if nitrification were to be stopped completely. Selmner-Olsen et al. (1971) reported that there were no changes in mineral- $\mathrm{N}$ with time if soil samples were stored at $-23^{\circ} \mathrm{C}$. The storage temperature used in the current experiment was $-10^{\circ} \mathrm{C}$. The significantly lower $\mathrm{NH}_{4}{ }^{+}-\mathrm{N}$ and $\mathrm{NO}_{3}{ }^{-} \mathrm{N}$ due to method 1 than due to any other drying method indicate that extraction for mineral $\mathrm{N}$ should be done on field moist soil sample.

\section{Effects of storage period on mineral nitrogen contents}

Storage periods had significant $(p=0.05)$ effect on both $\mathrm{NH}_{4}{ }^{+}-\mathrm{N}$ and $\mathrm{NO}_{3}{ }^{-} \mathrm{N}$ contents of the soils (Table 3). Storage period 1 (Period 1$)$ resulted in significantly $(p=0.5)$ highest $\mathrm{NH}_{4}{ }^{+}-\mathrm{N}$ contents of the experimental soils while there were no differences due to other storage periods (Table 4). There is no clear pattern of relationship between $\mathrm{NH}_{4}{ }^{+}-\mathrm{N}$ content of the soils with storage period. Periods 1 and 2 lead to similar but significantly lowest, while periods 4 and 5 gave significantly highest mean $\mathrm{NO}_{3}^{-}-\mathrm{N}$ contents of the soils (Table 4). 
The lack of effect of storage periods longer than two days after soil sampling (period 1) on $\mathrm{NH}_{4}{ }^{+}-\mathrm{N}$ content is in contrast to some reports but in agreement with some. Green et al. (1994) and Houba and Novozamsky (1998) reported that extractable $\mathrm{NH}_{4}{ }^{+}$-N contents of soils increased with storage time while Gray and Mclaren (2003) reported that extractable $\mathrm{NH}_{4}{ }^{+}-\mathrm{N}$ content of soils did not increase with storage period. However, Selmer-Olsen et al. (1971) observed that soil $\mathrm{NH}_{4}{ }^{+} \mathrm{N}$ increased in one day then decreased as storage period became longer. The authors also observed that storage of soil samples at $4^{\circ} \mathrm{C}$ in closed polyethylene bags decreased the content of $\mathrm{NH}_{4}{ }^{+}-\mathrm{N}$. The apparent lack of clear relationship between storage period and $\mathrm{NH}_{4}{ }^{+}-\mathrm{N}$ contents of the soils is attributed to the complex interactions of soil characteristics, fixed $\mathrm{NH}_{4}{ }^{+} \mathrm{N}$, drying temperature, and mineralization and immobilization rates (Aduayi, 1981; Sanchez et al., 2001). The significant $(p=0.05)$ increase of $\mathrm{NO}_{3}{ }^{-} \mathrm{N}$ contents of the soils with storage period is consistent with previous findings. SelmerOlsen et al. (1971) reported that soil nitrate- $\mathrm{N}$ increased with storage period. Gray and Mclaren (2003) also report that concentrations of $\mathrm{Ca}^{2+}, \mathrm{Mg}^{2+}, \mathrm{K}^{+}, \mathrm{Na}^{+}, \mathrm{NO}_{3}{ }^{-}, \mathrm{Cl}^{-}$and $\mathrm{SO}_{4}{ }^{2-}$ in soil solution increased with storage time. In the current study, however, the increase in $\mathrm{NO}_{3}{ }^{-}$was significant only after period 3 indicating low nitrification rate. These results show that all the storage periods used in the current experiment lead to significantly lower $\mathrm{NH}_{4}{ }^{+}-\mathrm{N}$ than did period 1 (control) indicating that stored soil samples did not reflect the situation of field moist soil.

\section{Differences in soils with respect to mineral nitrogen content}

The soils had significant $(p=0.05)$ differences in terms of mean $\mathrm{NH}_{4}{ }^{+}-\mathrm{N}$ and $\mathrm{NO}_{3}{ }^{-} \mathrm{N}$ contents (Table 3). Soil 1 had significantly $(\mathrm{p}=0.05)$ lowest $\mathrm{NH}_{4}{ }^{+}-\mathrm{N}$ and $\mathrm{NO}_{3}{ }^{-} \mathrm{N}$ contents, but there was no difference between soils 2 and 3 (Table 4). The magnitude of $\mathrm{NH}_{4}^{+}-\mathrm{N}$ released from a soil is influenced by the soil's initial \%C (Sertsu and Sanchez, 1978), \%N (Sanchez et al., 2001), and C:N ratio (Brady and Weil, 2002). The C:N ratio of each of the three soils was less than 20, a situation that allowed net mineralization to occur (Wong and Nortcliff, 1995). The authors report that decomposition rate is sometimes better related to the $\% \mathrm{~N}$ than C:N ratio and a critical level of $0.17 \% \mathrm{~N}$ was suggested for mineralization. Soil 3 with relatively high C:N ratio and $\% \mathrm{~N}$ of 15.6 and 0.18 , respectively gave the highest $\mathrm{NH}_{4}{ }^{+}-\mathrm{N}$ and $\mathrm{NO}_{3}{ }^{-} \mathrm{N}$, while, soil 1 with $\mathrm{C}: \mathrm{N}$ ratio and $\% \mathrm{~N}$ of 13.5 and 0.17 , respectively had the lowest $\mathrm{NH}_{4}{ }^{+}-\mathrm{N}$ and $\mathrm{NO}_{3}{ }^{-} \mathrm{N}$ contents. This observation is in agreement with the reports by Schomberg et al. (1994), Wong and Nortcliff (1995) and Sanchez et al. (2001). The significant difference in $\mathrm{NH}_{4}{ }^{+}-\mathrm{N}$ and $\mathrm{NO}_{3}{ }^{-} \mathrm{N}$ between soils 1 and 3 could be attributed to the differences in $\% \mathrm{~N}$ and $\mathrm{C}: \mathrm{N}$ ratios, but the differences between soils 1 and 2 could not be explained in terms of the differences in $\% \mathrm{~N}$ and $\mathrm{C}: \mathrm{N}$ ratios between the two soils. This suggests that there were other sources, besides organic matter, that contributed to the $\mathrm{NH}_{4}{ }^{+}-\mathrm{N}$ and $\mathrm{NO}_{3}{ }^{-} \mathrm{N}$ released from the soils. Frye and Hutcheson (1981) reported that both organic and inorganic exchangeable $\mathrm{N}$ contributed to the $\mathrm{NH}_{4}{ }^{+}-\mathrm{N}$ released from soils during oven drying. Green et al. (1994) also observed rapid (45\%) release of fixed $\mathrm{NH}_{4}{ }^{+}-\mathrm{N}$ during nitrification in 15 days. The released $\mathrm{NH}_{4}{ }^{+}-\mathrm{N}$ would then be nitrified to $\mathrm{NO}_{3}{ }^{-} \mathrm{N}$. These results indicate that other factors than organic $\mathrm{C}$ and $\mathrm{N}$ contributed to both $\mathrm{NH}_{4}{ }^{+}-\mathrm{N}$ and $\mathrm{NO}_{3}{ }^{-} \mathrm{N}$ released from the soils during drying and storage.

\section{Interactive effects of treatments on mineral $\mathrm{N}$ contents of the soils}

Interactions between the main treatments showed significant differences (Table 3). Soil 1 consistently gave significantly $(\mathrm{p}=0.5)$ lowest $\mathrm{NH}_{4}{ }^{+}-\mathrm{N}$ across methods 1,2 and 3 and periods 1, 2 and 3 combinations (Table 5). There were no differences amongst the soils across methods 4 and 5 , and periods 4 and 5 combinations. For each soil $x$ method combination, $\mathrm{NH}_{4}{ }^{+}-\mathrm{N}$ tended to decrease with storage period, but the relationship was not consistent. Method $1 \mathrm{x}$ period 1 (check) resulted in significantly $(p=0.05)$ lowest $\mathrm{NH}_{4}{ }^{+}-\mathrm{N}$ content for each soil compared to the other drying method $x$ storage period combinations (Table 5) indicating that none of the other combinations reflected status of the field moist soil. For each soil and each storage period, method 1 resulted in significantly $(p=0.05)$ lowest, while methods 2 and 3 resulted in the highest $\mathrm{NO}_{3}{ }^{-} \mathrm{N}$ contents (Table 5). Soil 3 had significantly $(\mathrm{p}=0.05)$ highest $\mathrm{NO}_{3}{ }^{-} \mathrm{N}$ content across the drying methods and storage periods compared to the other soils. The consistency of results relating to the experimental soils across the drying methods and storage periods indicate that the cylindrical block of soil used sufficiently controlled heterogeneity. However, since the check (method $1 \mathrm{x}$ period 1) resulted in both $\mathrm{NH}_{4}{ }^{+}-\mathrm{N}$ and $\mathrm{NO}_{3}{ }^{-} \mathrm{N}$ contents significantly different from those due to the other drying methods $x$ storage period combinations, there is still no method that allows for compositing and mixing Vertisols samples to obtain a representative sample from field moist collections.

\section{Conclusions}

Drying of soils, whether in air or in oven, consistently resulted in significant increase in $\mathrm{NH}_{4}^{+}-\mathrm{N}$ released from each soil under each storage period. The increase in $\mathrm{NH}_{4}{ }^{+}-$ $\mathrm{N}$ released is higher with oven drying. The higher the drying temperature, the higher is the amount of $\mathrm{NH}_{4}{ }^{+}-\mathrm{N}$ released from the soils. On the other hand the higher the drying temperature, the lower the amount of $\mathrm{NO}_{3}{ }^{-} \mathrm{N}$ released from the soils indicating that the higher temperatures (70 and $100^{\circ} \mathrm{C}$ ) employed in the oven drying in the current 
Table 5. Interactive effects of soils, drying methods, and storage periods on mineral nitrogen contents (mg $\mathrm{N} \mathrm{kg}^{-1}$ oven-dry soil) of the experimental soils.

\begin{tabular}{|c|c|c|c|c|c|c|c|c|c|c|c|}
\hline \multirow{3}{*}{ *Soil } & \multirow{3}{*}{$\begin{array}{l}\text { *Drying } \\
\text { method }\end{array}$} & \multicolumn{10}{|c|}{ *Storage period } \\
\hline & & \multicolumn{2}{|c|}{ Period 1} & \multicolumn{2}{|c|}{ Period 2} & \multicolumn{2}{|c|}{ Period 3} & \multicolumn{2}{|c|}{ Period 4} & \multicolumn{2}{|c|}{ Period 5} \\
\hline & & $\mathrm{NH}_{4}{ }^{+}$ & $\mathrm{NO}_{3}{ }^{-}$ & $\mathrm{NH}_{4}{ }^{+}$ & $\mathrm{NO}_{3}^{-}$ & $\mathrm{NH}_{4}{ }^{+}$ & $\mathrm{NO}_{3}^{-}$ & $\mathrm{NH}_{4}{ }^{+}$ & $\mathrm{NO}_{3}^{-}$ & $\mathrm{NH}_{4}{ }^{+}$ & $\mathrm{NO}_{3}$ \\
\hline & Method 1 & 17.2 & 0.1 & 16.4 & 0.4 & 17.1 & 0.3 & 23.1 & 0.3 & 14.7 & 0.4 \\
\hline & Method 2 & 22.5 & 0.7 & 19.2 & 0.7 & 18.2 & 0.7 & 24.9 & 0.7 & 19.2 & 0.7 \\
\hline \multirow[t]{3}{*}{ Soil 1} & Method 3 & 22.9 & 0.7 & 18.2 & 0.7 & 19.6 & 0.9 & 24.1 & 0.6 & 20.9 & 0.8 \\
\hline & Method 4 & 33.5 & 0.2 & 32.3 & 0.3 & 29.7 & 0.2 & 33.6 & 0.4 & 33.4 & 0.2 \\
\hline & Method 5 & 30.5 & 0.3 & 32.5 & 0.3 & 34.1 & 0.2 & 39.2 & 0.3 & 39.5 & 0.1 \\
\hline \multirow[t]{5}{*}{ Soil 2} & Method 1 & 21.7 & 0.2 & 20.8 & 0.2 & 23.4 & 0.3 & 19.6 & 0.3 & 12.6 & 0.6 \\
\hline & Method 2 & 27.6 & 0.5 & 24.6 & 1.7 & 27.4 & 0.7 & 25.4 & 1.3 & 20.9 & 1.0 \\
\hline & Method 3 & 28.3 & 0.6 & 28.9 & 2.0 & 28.0 & 0.8 & 21.2 & 0.8 & 28.3 & 1.2 \\
\hline & Method 4 & 36.3 & 0.2 & 30.4 & 0.3 & 32.4 & 0.4 & 35.7 & 0.7 & 34.0 & 0.8 \\
\hline & Method 5 & 33.6 & 0.2 & 28.4 & 0.3 & 33.3 & 0.4 & 35.0 & 0.6 & 41.1 & 0.7 \\
\hline \multirow[t]{5}{*}{ Soil 3} & Method 1 & 21.5 & 0.5 & 22.0 & 0.6 & 21.8 & 1.1 & 15.5 & 0.9 & 12.5 & 1.8 \\
\hline & Method 2 & 26.7 & 2.4 & 22.4 & 2.8 & 21.4 & 2.5 & 27.8 & 2.6 & 23.8 & 2.4 \\
\hline & Method 3 & 26.9 & 2.0 & 23.2 & 2.2 & 26.9 & 2.3 & 22.1 & 2.5 & 26.1 & 2.1 \\
\hline & Method 4 & 35.5 & 1.6 & 36.5 & 1.9 & 36.4 & 1.7 & 33.7 & 1.3 & 28.7 & 1.5 \\
\hline & Method 5 & 37.5 & 1.2 & 41.2 & 2.1 & 41.4 & 1.3 & 36.6 & 1.3 & 36.1 & 1.4 \\
\hline
\end{tabular}

The values are means of three observations. *Soils, drying methods and storage periods are as explained in Table 2 . $\mathrm{LSD}_{0.05} \mathrm{for}_{\mathrm{NH}_{4}}{ }^{+}$and $\mathrm{NO}_{3}{ }^{-}$are 3.9 and 0.3 , respectively.

study depressed the activities of nitrifying organisms. Since method 1 resulted in significantly lower $\mathrm{NH}_{4}^{+}-\mathrm{N}$ and $\mathrm{NO}_{3}^{-}-\mathrm{N}$ than did the other drying methods, it was concluded that none of the tested drying methods was suitable substitute for the use of field fresh soil sample for the determination of mineral $\mathrm{N}$ contents of Vertisols.

The relationship between $\mathrm{NH}_{4}^{+}-\mathrm{N}$ content of the soils and the storage period was not clear suggesting complex interactions involving soil characteristics, fixed $\mathrm{NH}_{4}{ }^{+}-\mathrm{N}$, drying temperature and mineralization and immobilization rates. The significant increase in $\mathrm{NO}_{3}^{-} \mathrm{-}$ with storage period only after period 3 indicated that storage temperature $\left(-10^{\circ} \mathrm{C}\right)$ depressed but did not eliminate nitrification. The consistency of $\mathrm{NH}_{4}{ }^{+}-\mathrm{N}$ and $\mathrm{NO}_{3}{ }^{-} \mathrm{N}$ contents in respect of each soil across the drying methods and storage periods suggested that the cylindrical block of soil used in the current experiment sufficiently checked heterogeneity of the soils.

Since method $1 \mathrm{x}$ period 1 , for each soil, resulted in $\mathrm{NH}_{4}{ }^{+}-\mathrm{N}$ and $\mathrm{NO}_{3}{ }^{-} \mathrm{N}$ contents significantly different from those due of the other drying method $x$ storage period combinations, it was concluded that extraction for mineral $\mathrm{N}$ should be done on field moist soil not later than two days after sampling. Further research should be conducted to determine drying method that would facilitate mixing of Vertisols samples and storage temperature that would retain mineral $\mathrm{N}$ content reflective of field moist soil status.

\section{ACKNOWLEDGEMENT}

We acknowledge with gratitude the financial assistance from the Rockefeller Foundation without which the study could not have been done.

\section{REFERENCES}

Aduayi EA (1981). Effects of duration and conditions of storing soil samples on soil chemical composition. Afr. J. Agric. Sci. 8:89-93.

Anderson JM, Ingram JSL (eds.) (1993). Tropical Soil Biology and Fertility: A Handbook of Methods. Tropical Soil Biology and Fertility, Nairobi, Kenya. $221 \mathrm{p}$

Anonymous (1995). Laboratory Methods for Soil and Plant Analysis. ICRAF: Nairobi, Kenya. 86 p.

Anonymous (1997). Soil Map of the World. Revised Legend with 
Corrections and Updates. ISRIC, Wageningen. The Netherlands. $97 \mathrm{p}$.

Anonymous (2010). GenStat $13^{\text {th }}$ Edition computer software for bioscience. VSN International Ltd, Hemel Hempstead, UK.

Aulakh MS, Doran JW, Mosier AR (1992). Soil denitrification, significant measurement and effects of management. Adv. Soil Sci. 18:1-57.

Bekunda M, Galloway J, Syers K, Scholes M (2007). Background, current status and the African context of the international nitrogen initiative. In: Batiano A, Waswa B, Kihara J, Kimetu J (ed). pp. 115-119.

Bernoux M, Arrouays C, Cerri C, Volkoff B, Jolivet C (2002). Brazil's soil carbon stocks. Soil Sci. Soc. Am. J. 66:888-896.

Birch FH (1958). The effect of soil drying on humus decomposition and nitrogen availability. Plant Soil 10(1):9-31.

Bouyoucos GF (1962). Hydrometer method improved for making particle size analysis of soils. Agron. J. 54:464-465.

Brady NC, Weil RR (2000). The Nature and Properties of Soils. $13^{\text {th }}$ Edition. Pearson Edition, Incl. Upper Saddle River, New Jersey, USA. $653 p$.

Bremner JM (1996). Nitrogen-Total. In: Sparks, L. (ed). Methods of Soil Analysis. Part 3-Chemical analysis. Soil Science Society of America, and America Society of Agronomy. Winsconsin, USA. p. 1085-1122.

Coulombe CE, Wilding LP, Dixon JB (1996). Overview of Vertisols: characteristics and impacts on society. Adv. Agron. 57:289-375.

Frye WW, Hutcheson Jr. TB (1981). Release of $\mathrm{NH}_{4}^{+}$in soils by oven drying. Soil Sci. Soc. Am. J. 45:889-892.

Gray CW, Mclaren RG (2003). Effects of air drying or sample storage on soil solution properties of biosolids amended soil. Commun. Soil Sci. Plant Anal. 34(15-16):2327-2338.

Green CJ, Blackmer AM, Yang NC (1994). Release of fixed ammonium during nitrification in soils. Soil Sci. Soc. Am. J. 58:1411-1415.

Houba VJG, Novozamsky I (1998). Influence of storage time and temperature of air-dried soils on $\mathrm{pH}$ and extractable nutrients using 0.01 $\mathrm{M} \mathrm{CaCl}_{2}$. Fresenius J. Anal. Chem. 360:362-365.

Linn DM, Doran JW (1984). Effect of water-filled pore space on carbon dioxide and nitrous oxide production in tilled and non-tilled soils. Soil Sci. Soc. Am. J. 48:1267-1272.

Magesan GW, White RE, Scotter DR, Bolan NS (2002). Effect of prolonged storage of soil lysimeters on nitrate leaching. Agric. Ecosyst. Environ. 88(1):73-77.

Nelson DW, Bremner JM (1972). Preservation of soil samples for inorganic nitrogen analysis. Soil Sci. Soc. Am. Proc. 64:196-199.

Okalebo JR, Gathua K, Woomer PL (2002). Laboratory Methods of Soil and Plant Analysis: A Working Manual. UNESCO, Nairobi, Kenya.pp. 128.
Recous S, Fresneau C, Faurie G, May B (1988). The fate of labeled ${ }^{15} \mathrm{~N}$ urea and ammonium nitrate applied to a winter wheat crop. I. Nitrogen transformations in the soil. Plant Soil 112:205-214.

Sakin E (2012). Relationships between carbon, nitrogen stocks and texture of the Harran Plain Soils in South-eastern Turkey. Bulg. J. Agric. Sci. 18(4):626-634.

Sakin E, Sakin ED, Binici T (2011). Soil organic carbon stocks of East Anatolia region in Turkey. American-Eurasian J. Agric. Environ. Sci. 10(5):776-780.

Sanchez EJ, Thomas CW, Kadir Kiziikaya, Parker E, Richard RH (2001). Enhancing the mineralizable Nitrogen pool through substrate diversity in long term cropping systems. Soil Sci. Soc. Am. J. 65:1442-1447.

Schomberg HH, Steiner JL, Wanger P (1994). Decomposition and nitrogen dynamics of crop residues. Residue quality and water effects. Soil Sci. Soc. Am. J. 58:372-381.

Selmer-Olsen AR, Øien A, Bærug R, Lyngstad I (1971). Pre-treatment and storage of soil samples prior to mineral nitrogen determination. Acta Agric. Scandinavicæ 21:57-62.

Sertsu SM, Sanchez PA (1978). Effect of heating on some changes in soil properties in relation to an Ethiopian land management practice. Soil Sci. Soc. Am. J. 42:940-944.

Sigunga DO (1997). Fertilizer Nitrogen Use Efficiency and Nutrient Uptake by Maize (Zea mays L.) in Vertisols in Kenya. PhD. Thesis. Wageningen University, The Netherlands. $207 \mathrm{p}$.

Smaling EMA, Bouma J (1992). Bypass flow and leaching of nitrogen in a Kenyan Vertisol at the onset of the growing season. Soil Use Manag. 8:44-48.

Stevenson FJ (1986). Cycles of Soil: Carbon, Nitrogen, Phosphorus, Sulphur, and Micronutrients. John Wiley \& Sons: New York. USA. $380 \mathrm{p}$.

Tripathi JK, Ladha JK (1997). Nitrogen dynamics and balance in intensified rain-fed lowland rice-based cropping system. Soil Sci. Soc. Am. J. 61:812-821.

Wiesler F, Horst WJ (1994). Root growth and nitrate utilization of maize cultivars under field conditions. Plant Soil 163:267-277.

Wong MTF, Nortcliff S (1995). Seasonal fluctuations of native available $\mathrm{N}$ and soil management implications. Fert. Res. 42:13-26. 